\title{
0 processo de valorização da escola como fundamento para intervenção no ambiente construído e na qualidade do lugar de aprendizagem
}

\author{
Rafael Ferreira Diniz Gomes ${ }^{1}$ \\ Giselle Arteiro Nielsen Azevedo²
}

RESUMO

A história da arquitetura escolar carioca demonstra que as soluções adotadas desde as primeiras unidades em meados do século XIX até os dias de hoje, possuem características de projeto padrão. Nos séculos passados, os edifícios escolares implantados no meio urbano dialogavam com o entorno expressando seu valor como marcos referenciais daquele contexto político sociocultural. No entanto, muitos desses edifícios ainda hoje se mantêm em uso, com a mesma função original educativa. A partir da aplicação conjunta dos conceitos, métodos e instrumentos de pesquisa relacionados à avaliação do ambiente construído, essa pesquisa procura verificar as condições de adaptabilidade de usos em uma escola de ensino fundamental da cidade do Rio de Janeiro. Através da valorização do patrimônio escolar e sua memória, procura-se justificar e condicionar, a partir de diretrizes projetuais, a permanência espaço-temporal dessa instituição. Esse estudo propõe que os processos de valorização da escola acontecem através do relacionamento dos conceitos de diversas pesquisas que tratam da interação usuário-ambiente escolar, para a construção do lugar de aprendizagem. Como resultados, percebeu-se que no geral a arquitetura escolar (inclusive a contemporânea) ainda não dialoga com os objetivos da educação, ponto chave para a sua permanência no contexto urbano e valorização social.

PALAVRA-CHAVE: Arquitetura escolar; Avaliação Pós-Ocupação; Representações sociais; Memória.

\section{ABSTRACT}

The history of Rio's school architecture shows that the solutions adopted from the first units in the mid-nineteenth century to the current days have standard design characteristics. In the past centuries, the school buildings implanted in the urban environment were in dialogue with the environment expressing their value as reference frames of that socio-cultural political context. However, many of these buildings still remain in use, with the same original educational function. Based on the joint application of concepts, methods and research instruments related to the evaluation of the built environment, this research seeks to verify the adaptability conditions of uses in a primary school in the city of Rio de Janeiro. Through the valorization of the school heritage and its memory, to justify and condition, from the design guidelines, the space-time permanence of this institution. This study proposes that the processes of valorization of the school happen through the relationship of the concepts of several researches that deal with the user-school environment interaction, for the construction of the Learning place. As a result, it was noticed that in general school architecture (including contemporary architecture) still does not dialogue with the objectives of education, a key point for its permanence in the urban context and social valorization.

KEY-WORDS: School architecture; Post-occupation evaluation; Social representations; Memory.

1 Mestre, Doutorando PROARQ/FAU/UFRJ, Universidade Federal do Rio de Janeiro, RJ - Brasil. Email: raffa.arq@globo.com

2 Dr., Professora Associada PROARQ/FAU/UFRJ, Universidade Federal do Rio de Janeiro, RJ - Brasil. Email: gisellearteiro@globo.com 


\section{Introdução}

É inegável e indiscutível a função social da escola para formação integral do ser humano. O edifício escolar, palco de todas essas atividades, tem papel preponderante para a socialização e a construção do conhecimento de crianças e jovens. Pensar sobre a qualidade dos ambientes que compõem a escola significa fortalecer as funções socioeducativas dessa instituição e a garantia do atendimento aos requisitos básicos de desenvolvimento dos seus usuários. A imagem da instituição escolar é impregnada de simbolismos e significados; a escola não é um elemento neutro na paisagem urbana. Pelo contrário, ao fazer parte de um contexto histórico, político e social, através da sua materialidade e presença no traçado urbano, podemos compreender um pouco a sociedade da qual fazemos parte. Em muitos casos, a permanência espaço-temporal da arquitetura, é a única porta de acesso aos mundos que já não existem, além do nosso imaginário, mas que insistem em emergir em nossas vidas de tempos em tempos. As escolas constituem importantes documentos para compreender o contexto sociocultural de determinado momento histórico.

Ao longo dos últimos anos, tem-se revivido inúmeras discussões e reflexões acerca do ensino no Brasil. As propostas pedagógicas atuais se distanciam do perfil adotado pelas escolas do século XIX e do começo do século XX. Segundo Azevedo (1995), naquela ocasião, as escolas possuíam uma proposta pedagógica mais severa e inflexível, com métodos de ensino mais rígidos, como o distanciamento de professores e alunos, através da simples disposição de mobiliários, com carteiras fixas dispostas em fileiras. O professor, por sua vez, ministrava suas aulas sobre tablados, impondo assim uma superioridade perante os alunos.

De modo a acompanhar as novas tendências educativas do município do Rio de Janeiro, deve-se analisar até que ponto o arranjo espacial e a arquitetura das escolas de ontem ${ }^{3}$, com excelente qualidade construtiva e arquitetônica, têm potencial de atualização dos seus usos e adequabilidade à mutabilidade do ensino. Diferentemente das práticas pedagógicas, que são mais transitórias, devido aos constantes processos de evolução, reciclagem e adaptação aos diferentes contextos políticos e sociais, a arquitetura é permanente. Possui um forte caráter espaço-temporal, traduzido em solidez e durabilidade. Nesse contexto, em que muitas pesquisas surgem com objetivo de levantar a discussão dos processos de projeto para a formulação dos novos edifícios escolares, com vistas aos novos conceitos pedagógicos, o que fazer com as instituições de ensino dos séculos passados, que permanecem ainda ativas nos dias de hoje? Essa inquietação constitui então o principal questionamento desse artigo.

A partir da aplicação conjunta dos conceitos, métodos e instrumentos de pesquisa relacionados à Avaliação Pós-Ocupação (APO) com abordagem experiencial, essa pesquisa, como parte de uma investigação em mestrado acadêmico concluído no ano de 2016, procura avaliar as condições de permanência e adaptabilidade de usos dessas instituições nos dias de hoje. Essa verificação se deu através da análise da organização espacial de uma edificação escolar com projeto-tipo do estilo Neocolonial, considerando a valorização do patrimônio escolar, para justificar e condicionar, a partir de um conjunto de diretrizes, a permanência espaço-temporal dessas instituições, enquanto marcos referenciais da arquitetura escolar e história da cidade do Rio de Janeiro.

Os pressupostos teóricos, por sua vez, versaram sobre conceitos de diversos campos do conhecimento, que tratam da interação usuário-ambiente escolar, tais como a Arquitetura, a Pedagogia, a Psicologia Social, a Psicologia Ambiental, a Geografia Humanística,

3 Adotaremos a expressão "escolas de ontem”, como as instituições escolares implantadas no município do Rio de Janeiro nos primeiros períodos de expansão da educação pública, datadas de períodos bem distantes da atualidade, mais precisamente entre 1870 até 1945. 
entre outros. Essa pesquisa se baseia em três referências fundamentais: o conceito de Representações sociais de Moscovici (1978; 2015); os conceitos de espaço e lugar, e territorialidade por Tuan $(1974 ; 1983)$ e Sommer (1973); e o conceito de Memória Coletiva por Halbwacks (1990). Ao considerar esse referencial teórico, entende-se que os processos de valorização do ambiente escolar são influenciados pelas representações desses espaços, que se feitas de forma positiva, podem estabelecer relações de pertencimento, afetividade e filiação com o lugar - característica fundamental para sua preservação. A escola como lugar de memória coletiva, principalmente os edifícios escolares históricos, pode contribuir com os processos de formação de identidade social, para a constituição do Lugar de Aprendizagem.

O artigo está estruturado em três etapas, a primeira representa a fundamentação teórica da pesquisa propriamente dita com a abordagem multidisciplinar da pesquisa, através do relacionamento das abordagens de representações sociais, o conceito de lugar e espaço pessoal, e memória coletiva, constata-se a importância da interação usuário-ambiente escolar para a construção do Lugar de aprendizagem. A segunda etapa refere-se à apresentação dos materiais e métodos da pesquisa de campo - a Avaliação Pós-Ocupação com uma abordagem multimétodos. Procurou-se relacionar a fundamentação teórica com a escolha da metodologia de análise e os instrumentos de pesquisa utilizados nos estudos de caso a fim de responder as principais questões dessa pesquisa. Por fim, na terceira etapa é apresentado o estudo de caso da pesquisa, descrevendo inicialmente o contexto histórico da instituição e o momento atual em que se encontra. Em seguida, a aplicação dos instrumentos de Avaliação Pós-Ocupação. Pretende-se mostrar os resultados obtidos com a aplicação dos instrumentos, através do cruzamento dos dados e as recomendações para a adequação de uso dos espaços escolares analisados, sob a forma de matriz (matriz de descobertas e matriz de recomendações).

\section{0 processo de valorização do ambiente escolar}

O questionamento sobre a qualidade de vida no ambiente construído vem sendo sustentado por diversas pesquisas na área de Arquitetura, Urbanismo e da Psicologia ambiental. A colaboração entre essas disciplinas oferece diversas possibilidades para o estudo das relações psicológicas e psicossociais entre o homem e o meio em que ele se insere. Nesse sentido, Duarte (2002) atenta para a questão de que a arquitetura não é apenas a delimitação de um espaço físico, mas é também um fechamento cultural, e o ato de projetar significa buscar a satisfação de várias expectativas do homem em relação ao seu ambiente, seja permitindo o livre desempenho de suas atividades, seja proporcionando melhores condições de conforto ambiental, proporcionando a geração de afetos e a atribuição de significados ao lugar.

Del Rio (2002) aponta para o fato de que antes da intervenção projetual e da ação ambiental, é primordial o entendimento das necessidades e expectativas dos usuários para com o ambiente construído. Em suas palavras, "é preciso que estejamos conscientes das consequências previstas dessas ações e dos seus reflexos psicossociais para a sociedade futura" (DEL RIO, 2002, p. 203).

No campo da Psicologia Social e do estudo dos significados, a Teoria das Representações Sociais tem sido amplamente estudada e utilizada para compreender os diversos significados dados aos ambientes. "A possibilidade de ligação entre as teorias do lugar e as teorias desenvolvidas pela Psicologia Social acrescenta elementos importantes para a compreensão e avaliação das transações do sujeito e os ambientes" (SAGER, 2002, p. 28).

A seguir, são apresentados alguns conceitos dessa teoria, procurando entender como os processos de representação podem auxiliar na reflexão sobre a importância dos espaços 
escolares e como esse artefato social com todo o seu caráter simbólico é percebido e vivenciado por seus usuários.

\subsection{Representação social do edifício escolar}

A teoria das Representações sociais surgiu na Europa, mais precisamente na França, em meados do século XX, quando o psicólogo Serge Moscovici preocupou-se em estudar as representações dos franceses sobre os termos da psicanálise. A partir desse ponto ele pôde compreender que, na falta de uma linguagem específica que permitisse as pessoas definirem algum acontecimento, características ou comportamentos, elas se apropriavam de termos não tão usuais para expressarem seus pensamentos. Os indivíduos pensam através de uma linguagem. As palavras e seus significados são utilizados para classificar coisas, pessoas e atitudes. Essas classificações, portanto, são baseadas nas representações sociais, da imagem simbólica com que as pessoas compreendem o mundo (o sentido figurado, ou conotativo da linguagem, é resultado de representações). Assim, segundo sua visão, "todos os sistemas de classificação, todas as imagens e todas as descrições que circulam dentro de uma sociedade, mesmo as descrições científicas, implicam um elo de prévios sistemas e imagens".

Representações sociais são sistemas de valores, noções e práticas com duas funções principais: primeiro, estabelecer uma ordem que permita aos indivíduos orientarem-se e manterem-se donos de seu mundo material e, segundo, facilitar a comunicação entre os membros de uma comunidade, provendo-os com um código para nomear e classificar aspectos de seu mundo e sua história individual e em grupo. (MOSCOVICl, 1978, p. 23)

As representações sociais são entidades quase tangíveis. Elas circulam, se entrecruzam e se cristalizam continuamente, através duma palavra, dum gesto, ou duma reunião, em nosso mundo cotidiano. Elas impregnam a maioria de nossas relações estabelecidas, os objetos que nós produzimos ou consumimos e as comunicações que estabelecemos. (MOSCOVICl, 1961;1976, apud. MOSCOVICl, 2015, p. 10).

O termo "escola (do latim schola)" no dicionário de língua portuguesa é definido como "casa ou estabelecimento em que se ministra ensino de ciências, letras ou artes", ou ainda "conjunto de alunos e professores". Levando-se em consideração somente essas duas definições, então temos para um mesmo significante, dois significados distintos, um que associa o termo "escola" a um objeto físico, material, um ambiente e suas atividades, enquanto que o outro faz uma referência aos usuários, conjunto de pessoas. As representações de escola feitas no âmbito social levam em consideração a relação entre ambiente e seus prováveis usuários.

O prédio escolar se confunde com o próprio serviço escolar e com o direito à educação. Embora colocado no rol dos itens secundários dos programas educativos, é o prédio da escola que estabelece concretamente os limites e as características do atendimento. E é ainda esse objeto concreto que a população identifica e dá significado. (LIMA, Mayumi Souza,1995, p. 75.).

Ao mesmo tempo em que exerce a função de abrigar a dinâmica do ensino, a escola constitui-se como um símbolo do estado ou das elites, polo disseminador da cultura adotada como oficial. Desde que o ensino básico tornou-se obrigatório no Brasil (Constituição Imperial de 1824), a imagem arquitetônica da escola pública sempre foi objeto de divulgação política do poder instituído junto à população. Nos governos populistas esta aproximação fez-se mais forte, embasada por grandes projetos pedagógicos que se refletiam na arquitetura como programa e, ao mesmo tempo, utilizavam-na como símbolo. 
Entendendo o edifício escolar como instituição social que contém significados na sua arquitetura, como uma espécie de símbolo no contexto urbano e social, ele está ligado a um processo cognitivo que permite à sociedade compreendê-lo e relacionálo no próprio traçado urbano. A arquitetura escolar, portanto, deveria representar e comunicar a "ideia" de escola que alguns grupos sociais concebem. Essa visão seria o produto da representação social. Então, segundo essa teoria, a representação social é o sinal e a reprodução de um objeto socialmente identificado (como a escola) e o ato de representar facilita a tarefa de decifrar, predizer ou antecipar os atos de um indivíduo ou grupo relacionados àquele objeto (ato político). (MOUSSATCHE et al., 2002).

Segundo Moussatche et al. (2002), de acordo com essa teoria, as propostas arquitetônicas do edifício escolar - materiais, visíveis e quantificáveis - apresentados à sociedade constituem uma objetivação concreta do poder público a uma idealização abstrata da instituição escola, construída no âmbito psicossocial dos grupos que a concebem. Ou seja, mesmo que os futuros usuários do edifício escolar não sejam levados em consideração ainda nas fases iniciais do projeto de arquitetura, o edifício vai acabar sendo projetado para se adequar as necessidades desses usuários, que são de certo modo, representantes de uma cultura.

\subsection{Arquitetura escolar - lugar, espaço e tempo}

O estudo da teoria das representações sociais nos permite enxergar que inevitavelmente cada indivíduo nasce em um mundo carregado de conceitos, visões e pensamentos preconcebidos, e que certamente, definem o modo como enxergamos e vivenciamos os espaços por onde se desenvolvem as nossas relações sociais. O ser humano, ao experienciar o seu espaço de vivência, assim como os espaços de aprendizagem, adquire respostas, estímulos, que aos poucos vão definindo sentimentos como afetividade ou repulsa na interação usuário-ambiente.

Através das pesquisas do geógrafo Yi-Fu Tuan (1983), na Geografia Humanística, surgem as origens e definições dos conceitos de "lugar" e "espaço". "Lugar" seria então o "espaço ocupado", ou seja, habitado e o processo de transformação do espaço em lugar passaria pela perspectiva experiencial.

$\mathrm{O}$ autor define a experiência como termo que abrange os diferentes modos como o ser humano constrói seu conhecimento e sua realidade. A experiência do lugar está intimamente ligada à capacidade de aprender a partir da própria vivência, que pode se tornar real através da exploração dos sentidos, desde o tato, passando pela audição, olfato e paladar, até a percepção visual, como também da leitura simbólica desse lugar.

Na abordagem de Tuan (1983) o conceito de espaço frequentemente se funde com o de lugar, uma vez que as duas categorias não podem ser compreendidas uma sem a outra. Segundo o autor, o que começa como um espaço indiferenciado, transforma-se em lugar à medida que o conhecemos melhor e o dotamos de valor. "Quando o espaço nos é inteiramente familiar, torna-se lugar". Tuan ainda relaciona o Tempo e o Lugar de três formas: adquirimos afeição a um lugar em função do tempo vivido nele; o lugar seria uma pausa na corrente temporal de um movimento, ou seja, o lugar seria a parada para o descanso, para a procriação e para a defesa; e por último, o lugar seria o tempo tornado visível, isto é, o lugar como lembrança de tempos passados, pertencente à memória.

A experiência de espaço e tempo é principalmente subconsciente. Temos um sentido de espaço porque podemos nos mover e de tempo porque, como seres biológicos, passamos fases recorrentes de tensão e calma [...] quando mentalmente nos movemos no espaço, também avançamos e retrocedemos no tempo (TUAN, 1983, p. 132). 
Figura 1 - esquema gráfico sobre o conceito de Lugar segundo Tuan.
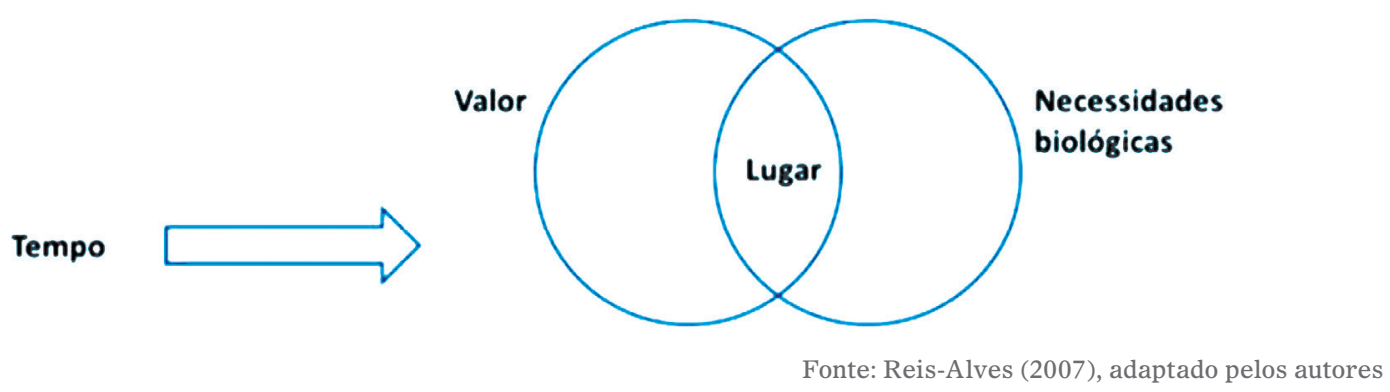

Através dos conceitos de espaço e lugar, como podemos compreender o processo de transformação do espaço escolar em lugar de aprendizagem? Azevedo (2012) dá algumas pistas. Através do reconhecimento de que a criança é o principal usuário da escola, a reflexão sobre as suas necessidades de desenvolvimento - físico, afetivo e intelectual torna-se essencial requisito para a formulação do ambiente educacional.

Sanoff (1994), através do conceito de "escola responsiva" relaciona os ambientes de aprendizagem com a imagem do lugar do conhecimento, substituindo a imagem de que a escola é um ambiente neutro que armazena crianças e adultos. Através das metodologias de projeto participativo ${ }^{4}$, entende que o melhor caminho para projetar espaços adequados ao uso das pessoas (e isso inclui a arquitetura escolar), é tentar compreender o que é importante para elas, tal como parte fundamental do processo de projeto. Então, se quisermos avaliar a percepção que as crianças têm do espaço escolar, algumas questões devem ser respondidas: qual a imagem dos ambientes educacionais na atualidade? Qual é a representação social de escola? Esses ambientes reconhecem as necessidades dos seus usuários?

\subsection{Escola: Lugar de Memória}

O edifício escolar, como ambiente construído imbricado de relações sociais, ao reunir num mesmo espaço um determinado número de pessoas de um bairro ou cidade, possui nessa característica a base fundamental da construção de memória coletiva. Entende-se por memória coletiva o conjunto de memórias individuais de um grupo social. Esse conceito foi criado por Maurice Halbwachs, sociólogo francês, primeiro estudioso das relações de memória e história pública.

Halbwachs (1990) enfatiza que o fator social da memória precede o fator individual. Segundo essa abordagem, a memória individual existe sempre a partir de uma memória coletiva, e ela depende das relações de convívio estabelecidas nos variados quadros sociais. As nossas impressões dos lugares, das pessoas e dos objetos, da nossa realidade, são apoiadas não só em nossas lembranças, mas também sobre as lembranças dos outros. A influência das experiências de vida de outras pessoas orienta nossas percepções das coisas, de modo que elas não são mais um fenômeno individual, e sim coletivo.

Nossas lembranças permanecem coletivas, e elas nos são lembradas pelos outros, mesmo que se trate de acontecimentos nos quais só nós estivemos envolvidos, e com objetos que só vimos. É porque, em realidade, nunca estamos sós. Não é necessário que outros homens estejam lá, que se distingam materialmente de nós: porque temos sempre conosco e em nós uma quantidade de pessoas que não se confundem. (HALBWACKS, 1990, p. 26)

\footnotetext{
4 Metodologia proposta por Henry Sanoff, arquiteto e professor titular da School of Design, North Carolina State University e autor de diversos livros sobre metodologias de projeto e participação comunitária. Esse método parece agir levando em consideração os saberes de todos os envolvidos no processo de projeto (conceito de desenho participativos.Segundo seus pensamentos "Os edifícios devem satisfazer as necessidades das pessoas que o usam. A gente que usa os edifícios também é experiente”
} 
Para Halbwachs (1990) não há interações sociais que não tenham relação com um lugar. Como pano de fundo dessas interações, o lugar recebe a marca das pessoas e vice-versa e gera imagens na memória coletiva. As escolas podem ser consideradas lugar de memória porque nesses espaços são produzidas parte das memórias sociais. Diversos são os atores que compõem o ambiente escolar, que vão desde os alunos, professores e funcionários, até os pais e as comunidades locais. Essa conjunção de pessoas é palco fértil para a consolidação de conhecimentos, experiências, convivência, e essas relações estruturam nossas memórias individuais e coletivas de um determinado momento de nossas vidas.

Lembrar do espaço escolar é lembrar também do entorno, do trajeto que leva da casa à escola, percurso de descoberta e manipulação, de aventuras e perigos, de brincadeiras e desafios. É uma memória que se enraíza nos gestos de um local concreto e que se torna emblemática quando é conferida à instituição que lhe dá suporte a transmissão dos valores da nação. Remete a um tempo preciso que a lembrança nostálgica muitas vezes esgarça. É o sinal de que se reconhece e pertence a certo grupo social e a uma determinada geração. (NUNES, 2001, p. 7)

O fato é, que geralmente só é valorizado aquilo que se conhece, assim como preconiza Tuan $(1983$, p. 83) "o que começa como espaço indiferenciado transforma-se em lugar à medida que o conhecemos melhor e o dotamos de valor. [...] $\mathrm{O}$ espaço transforma-se em lugar à medida que adquire definição e significado." E o conhecimento da história e do contexto sociocultural desses lugares de memória certamente irá contribuir com o sentido de pertencimento e filiação ao lugar.

A história das escolas, especialmente as mais antigas, tem se distanciado demais da história do indivíduo da atualidade, para que este se considere como parte dela. Se não nos consideramos como parte de um lugar, mesmo que esse lugar seja uma memória, não desenvolvemos relações íntimas com ele. Os lugares íntimos são como lugares onde encontramos carinho, onde nossas necessidades fundamentais são consideradas (TUAN, 1983). O resultado dessa falta de afetividade para com o ambiente construído de certo modo desencadeia processos de falta de identidade de desvalorização dos lugares que habitamos.

Enfim, sendo os edifícios escolares, antigos ou atuais, portadores de uma história e de uma memória carregada pelo tempo, parece que somente este fato não é suficiente para que eles sejam valorizados. É preciso que essa história e essa memória sejam compartilhadas tanto para a comunidade escolar como também para a sociedade. A construção de "lugar" baseado na "memória" parece ser um caminho para o processo de valorização do patrimônio cultural da cidade.

Assim, podemos atribuir os processos de valorização da escola ao relacionarmos os três principais conceitos analisados nessa pesquisa, conforme a imagem a seguir:

Figura 2 - o processo de valorização da escola.

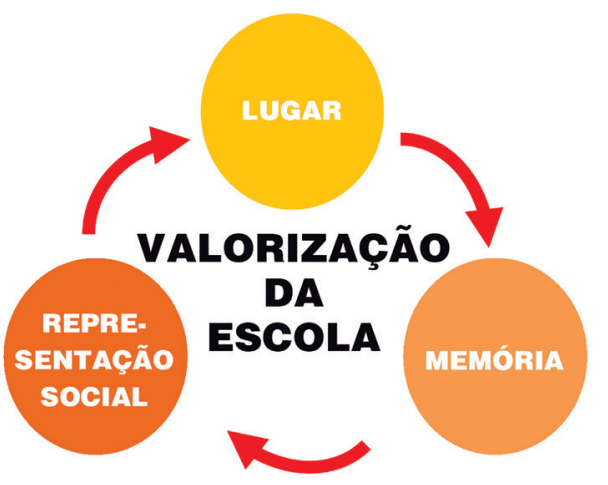




\section{Materiais e Métodos}

A metodologia escolhida para a pesquisa de campo é a Avaliação Pós-Ocupação (APO) através de uma abordagem multimétodos. A escolha dessa abordagem justifica-se por representar, entre outros aspectos, a importância da união entre técnicas de avaliação do ambiente construído no campo da Arquitetura com outros campos de pesquisa referentes aos estudos pessoa-ambiente, essencial na construção da qualidade do lugar.

Para atender aos objetivos do estudo, que pretende avaliar as condições de adaptabilidade de usos em escolas de ensino fundamental representativas de períodos emblemáticos da produção de arquitetura escolar carioca, e sua valorização enquanto instituição social foi escolhido um estudo de caso. Assim, de acordo com a o inventário de classificação tipológica da arquitetura escolar carioca ${ }^{5}$ proposta por Rachel Sisson (1990), no período que envolve os anos de 1870 até 1945, foi selecionada a Escola Municipal Sarmiento - de estilo Neocolonial, do período da República Velha.

$\mathrm{Na}$ análise foram enfatizados os aspectos de funcionalidade e aspectos cognitivos relacionados à interação usuário-ambiente escolar. Foi possível entender também qual a imagem e a representatividade social da escola por seus usuários, seu grau de satisfação com o ambiente construído, além da influência do caráter histórico e cultural dessas instituições na formação da memória e identidade social, na valorização do ambiente escolar e consequentemente em sua preservação. A abordagem dos aspectos projetuais, de composição e de construção se deu na avaliação da qualidade arquitetônica e construtiva dessas instituições, e como a questão da preservação da arquitetura escolar pode favorecer ou não para a permanência espaço-temporal dessas escolas, mantendo suas funções educativas.

Para verificar as questões descritas acima, foram utilizados instrumentos de avaliação do ambiente construído, com base nas metodologias de Avaliação Pós-Ocupação de importantes grupos de pesquisa, como o Grupo Ambiente-Educação $(G A E)^{6}$ e o Grupo de Pesquisa Qualidade do Lugar e Paisagem (ProLUGAR) ${ }^{7}$, e suas pesquisas relacionadas aos processos de percepção ambiental, fatores culturais e relacionamento entre homem e seu ambiente.

Os métodos adotados compreenderam etapas de revisão bibliográfica, o levantamento fotográfico e a aplicação de seis ferramentas de avaliação de desempenho: análise walkthrough, mapa comportamental, entrevista, mapa mental, poema dos desejos e seleção visual. A documentação indireta possibilitou a revisão da literatura mediante pesquisa bibliográfica sobre os conceitos de espaço, lugar, memória e representações sociais, bem como avaliação pós-ocupação. O levantamento fotográfico, por sua vez, foi utilizado para a obtenção de imagens da área de estudo.

No tocante às ferramentas de avaliação pós-ocupação, a análise walkthrough e o mapa comportamental permitiram o reconhecimento do lugar e registro de rotinas e primeiras

$5 \quad$ Esse inventário tem uma proposta de investigar os edifícios situados no município do Rio de Janeiro que foram ou ainda são utilizados como escolas públicas do primeiro grau. Através da identificação e enumeração de conjuntos desses edifícios formados com base em afinidades histórico/tipológicas, um recorte cronológico foi alcançado, balizado por dois momentos importantes da expansão da educação pública da cidade. São eles: a. 1870/1889: as escolas do Imperador; b. 1889/1926: o ecletismo republicano; c. 1926/1930: o estilo missões/ neocolonial; d. 1930/1945: o Modernismo arquitetônico.

6 O Grupo Ambiente-Educação (GAE) é um grupo de pesquisa vinculado ao PROARQ-FAU/UFRJ, sob a coordenação da Profa. Giselle Arteiro Nielsen Azevedo (http://www.gae.fau.ufrj.br). Valorizando a colaboração e a pesquisa interdisciplinar e interinstitucional, o grupo foi constituído em 2002, e desde então tem se dedicado ao estudo do ambiente construído para uso educacional, tendo como foco principal a reflexão sobre os ambientes destinados à Educação.

7 O ProLUGAR é um grupo interdisciplinar constituído em 1997, vinculado ao PROARQ-FAU/UFRJ, sob a coordenação dos Profs. Paulo Afonso Rheingantz e Vera Regina Tângari (http://www.fau.ufrj.br/prolugar/). Ao longo dos anos, o grupo tem se dedicado ao estudo da teoria e do projeto de arquitetura e suas diversas interfaces interdisciplinares, com ênfase na percepção ambiental e a qualidade do lugar na produção de um ambiente construído mais responsivo e sustentável. 
impressões acerca do objeto de estudo. A partir disso, o mapa mental e seleção visual foram adotados para a compreensão da imagem, representação social e constituição de memórias coletivas do ambiente para os usuários, e o poema dos desejos para registrar seus anseios e demandas. A entrevista, semi-estruturada, com este mesmo fim, mas destinada aos gestores, professores e alguns funcionários (RHEINGANTZ et al., 2014).

Quadro1 - organização da metodologia de avaliação pós-ocupação adotada na pesquisa

\begin{tabular}{|c|c|c|}
\hline INSTRUMENTO & TIPO DE ANÁLISE & AVALIAÇÃO \\
\hline Análise Walkthrough & $\begin{array}{c}\text { Aspectos funcionais, aspectos } \\
\text { compositivos e conforto ambiental. }\end{array}$ & Pesquisador \\
\hline Mapa Comportamental & $\begin{array}{c}\text { Uso e apropriação dos espaços de } \\
\text { recreação. }\end{array}$ & Pesquisador \\
\hline Entrevista & $\begin{array}{c}\text { Aspectos funcionais e reconhecimento } \\
\text { do edifício escolar (usos). }\end{array}$ & $\begin{array}{c}\text { Gestores, professores e } \\
\text { funcionários }\end{array}$ \\
\hline Mapa Mental & $\begin{array}{c}\text { Imagem, valor e representações do } \\
\text { edifício escolar. }\end{array}$ & Alunos \\
\hline Poema dos Desejos & $\begin{array}{c}\text { Anseios e desejos em relação ao espaço } \\
\text { educativo. }\end{array}$ & Todos os usuários \\
\hline Seleção Visual & $\begin{array}{c}\text { Memória } \\
\text { Matriz de Descobertas e de Recomendações }\end{array}$ & Pesquisador \\
\hline
\end{tabular}

Fonte: arquivo dos autores.

\section{Estudo de caso: Escola Municipal Sarmiento}

\subsection{0 edifício escolar}

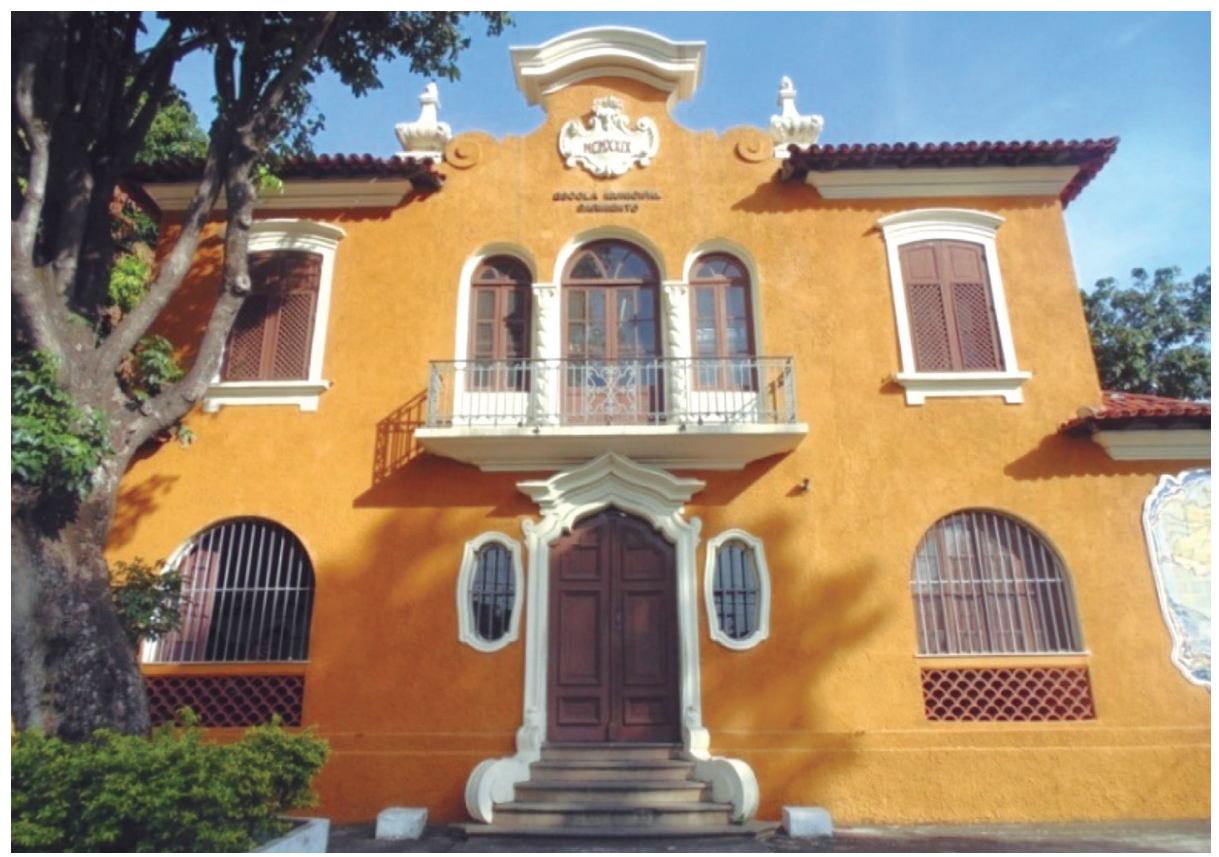

Figura 3 - Fachada da Escola Municipal Sarmiento

A Escola Municipal Sarmiento, construída em 1928, localiza-se no Engenho Novo, um bairro tradicional na Zona Norte do município do Rio de Janeiro. Trata-se de um edifício tombado pelo município, por ser exemplo da arquitetura carioca na primeira metade do século. O prédio escolar (figura 3) é composto por um conjunto edificado 
com três pavimentos, fachada simetricamente organizada, com vãos em arcos, com muxarabis e gelosias, telhas coloniais, dois grandes mapas compostos por azulejos dos dois lados da fachada principal e acesso centralizado e elevado ao nível da rua. Com uma arquitetura típica Neocolonial, movimento que se propunha a resgatar uma arte genuinamente nacional, o edifício apresenta uma exuberância construtiva e compositiva, imponência e destaque no entorno, tornando-se um marco referencial do bairro do Engenho Novo.

Internamente o edifício é organizado em torno de um corredor central e uma sucessão de pátios laterais por onde acontecem os acessos aos diversos ambientes da escola (nas laterais as salas de aula, sanitários, e ao fundo pátio coberto e refeitório). Com um terreno muito comprido, o edifício escolar é bastante alongado no sentido do comprimento do lote, característica que torna a escola ampla e com uma enorme quantidade de espaços e salas. A escola é formada pelos seguintes setores e respectivos ambientes (figuras 4,5 e 6): o conjunto pedagógico, com as diversas salas de aula, sala de leitura, auditório e laboratório de informática; o conjunto de vivência e assistência, com os corredores, os pátios laterais, pátio coberto, a quadra de esportes, o refeitório, os sanitários e o playground; o conjunto administrativo e de apoio pedagógico, com sala da diretoria e secretaria, sala dos professores e de apoio técnico; o conjunto de serviços, com cozinha, despensa depósitos, sanitário para funcionários da cozinha e a casa do caseiro.

Figura 4 - Planta baixa do térreo da Escola Municipal Sarmiento

ANÁLISE WALKTRHOUGH - NUMERAÇÃO DOS AMBIENTES Planta baixa do pavimento térreo

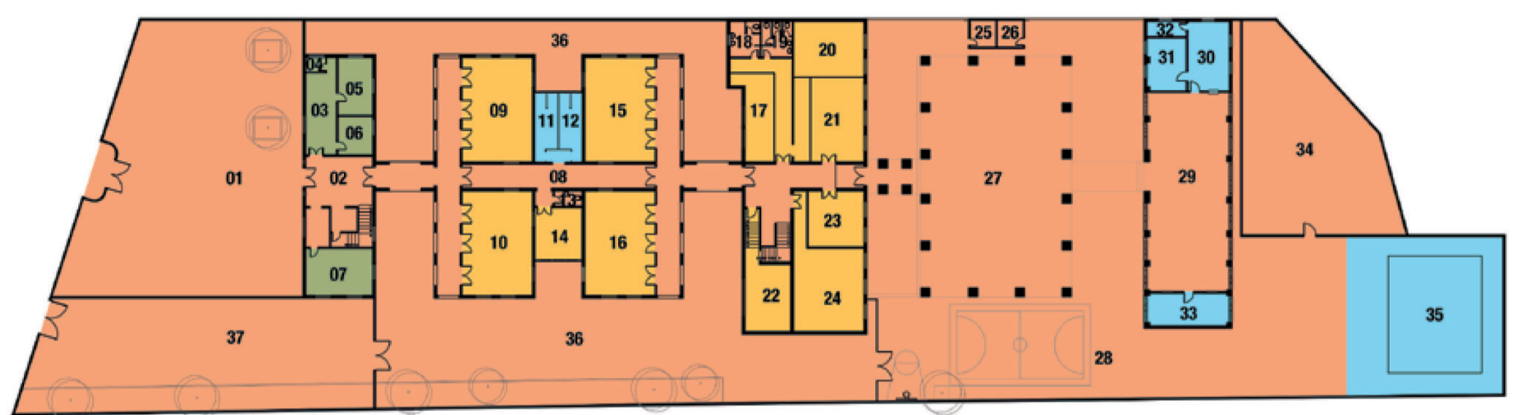

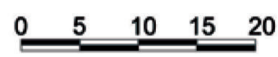

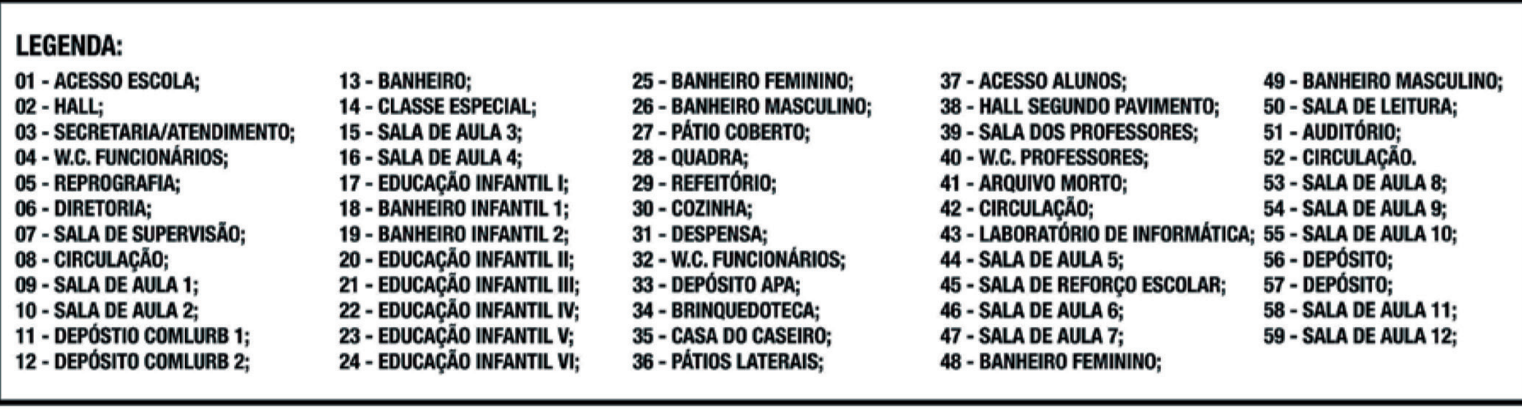




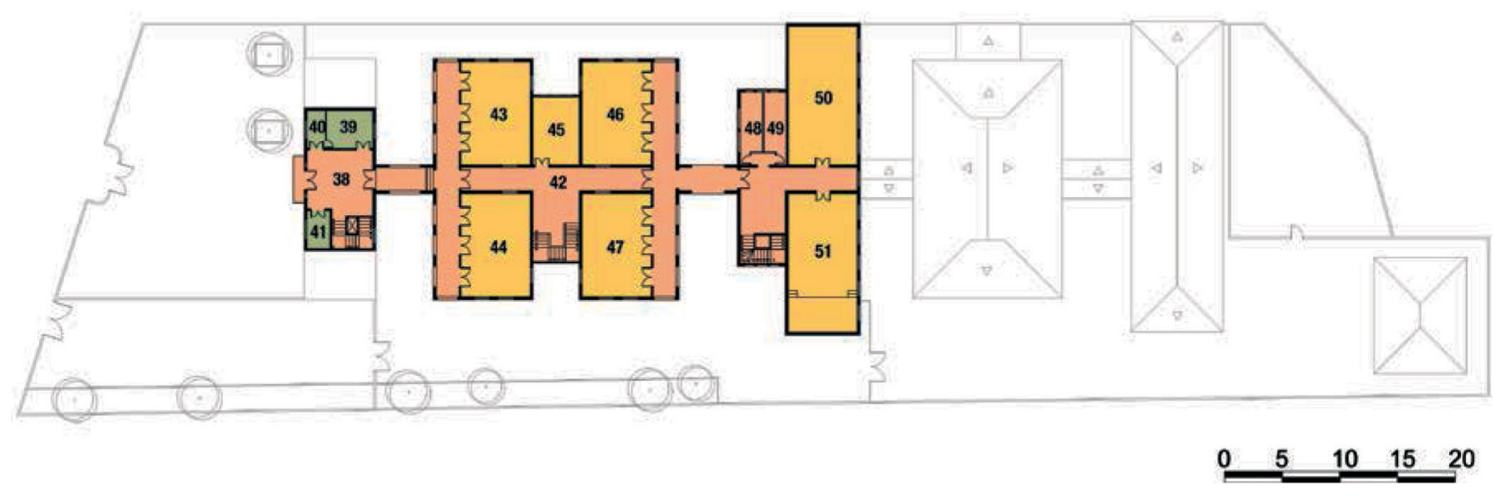

Fonte: arquivo dos autores.

Figura 6 - planta baixa do segundo pavimento da Escola Municipal Sarmiento

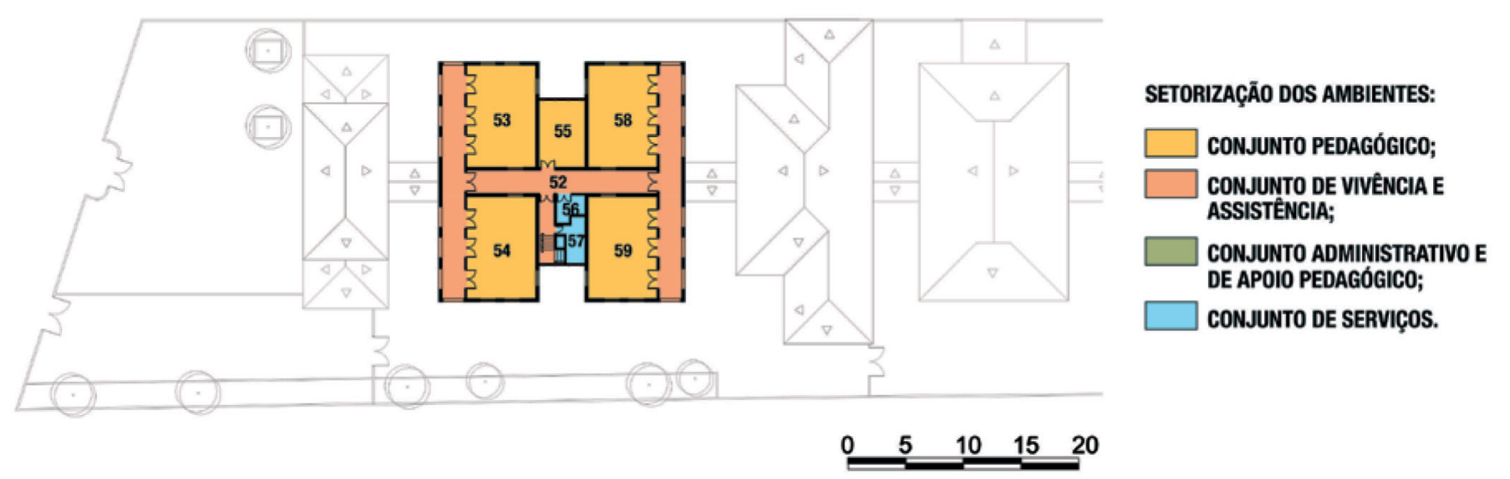

Fonte: arquivo dos autores.

\subsection{Ferramentas de APO: análise dos resultados}

Uma vez aplicadas, as ferramentas utilizadas, aqui apresentadas cronologicamente, forneceram importantes dados para a elaboração da matriz de descobertas. A Análise walkthrough é um instrumento de avaliação pós-ocupação que geralmente precede outros estudos e levantamentos, pois é capaz de fornecer uma visão geral acerca do desempenho ambiental do edifício. Através da sua aplicação, é possível identificar pontos positivos e negativos da edificação e seu uso, auxiliando a preparação dos demais instrumentos, e destacando aspectos a serem aprofundados (RHEINGANTZ et al., 2009). Nessa pesquisa, buscou-se aplicar uma análise walkthrough através de uma abordagem experiencial, para conhecer mais profundamente as características físicas das escolas, integrando as informações obtidas através das observações diretas, com os relatos dos acompanhantes no percurso, quando isso foi possível, o percurso dialogado, geralmente com os gestores ou outros funcionários das escolas.

O instrumento foi aplicado nos dias 09 e 21 de outubro de 2015. Como resultados, foram constatadas as seguintes características positivas: localização e identificação do edifício, imagem, formas e padrões construtivos, aspectos de conservação, orientação e legibilidade. A instituição é bastante privilegiada com relação aos espaços livres. Os ambientes possuem uma boa interação com os pátios internos, o que permite que as salas de aula tenham uma boa comunicação com o exterior e a criação de um microclima mais agradável nos ambientes internos. Boa apropriação 
dos espaços pelos estudantes, com respectiva demarcação do território e ativa socialização entre eles. Dentre os aspectos negativos, podemos citar: a escola está localizada em frente a uma estação de trem, por conta disso há diversos problemas de ruído, que atrapalham as atividades pedagógicas que são realizadas no local. As salas de aula, e demais salas, embora sejam amplas, possuem uma organização que não otimizam seus espaços, possuem muitos mobiliários e são superlotadas. Falta de melhor apropriação corredores (faltam murais e espaços mais atrativos). A acessibilidade universal é inexistente.

A Entrevista é uma das técnicas de trabalho mais utilizada em pesquisas na área de ciências sociais. Através de um conjunto de informações sobre o modo como as pessoas pensam, sentem, fazem, conhecem, acreditam e esperam sobre determinadas questões. A interação entre o pesquisador e o entrevistado é preponderante para o sucesso da sua aplicação (RHEINGANTZ et al, 2009).

Nessa pesquisa foram realizadas entrevistas semiestruturadas com a diretora da escola, e também conversas informais com os demais usuários, professores e funcionários, a fim de reconhecer ao máximo as principais características dos espaços estudados. A aplicação do instrumento ocorreu no dia 09 de outubro. Para a maioria dos entrevistados, a história e memória são fundamentais para o processo de valorização e conservação da escola. Segundo a diretora, a escola é identificada pela população local como instituição de ensino devido ao tempo de existência do prédio. Porém o tombamento encarece e dificulta as obras de manutenção, porque esse processo se torna muito oneroso. Para os professores, o tamanho das salas de aula permite a realização de diversas atividades. As reclamações ficam por conta do calor, e também o forte barulho do exterior que atrapalha demais as aulas, devido à passagem do trem e o ruído oriundo das circulações da escola. No geral o mobiliário foi identificado como insatisfatório, com necessidade de manutenção ou troca.

O Mapa comportamental é um dos instrumentos passíveis de utilização em avaliação pósocupação, que possibilita a obtenção de um registro sistematizado do comportamento dos usuários de um determinado ambiente. Esse instrumento é expresso pela representação gráfica dos comportamentos e atividades pessoais nos espaços analisados. A partir da aplicação dessa ferramenta, é possível analisar condutas, usos, layouts e demais interações entre os indivíduos e o espaço (Rheingantz et al., 2009). O instrumento foi aplicado nos dias 16 e 22 de outubro de 2015, no período da manhã e tarde respectivamente, onde foi avaliado o funcionamento geral do recreio, no pátio coberto e a quadra descoberta. O objetivo da era diagnosticar e registrar as atividades, os aspectos comportamentais e de apropriação dos usuários da escola nos ambientes de vivência e recreação, além de refletir acerca das condições físicas desses espaços para a realização de tais atividades. Os materiais utilizados para a aplicação do instrumento foram as fichas de registro do mapa comportamental, previamente desenvolvidas, que continham as plantas baixas dos ambientes selecionados, a fim de poder captar uma quantidade maior de informações possíveis.

Como resultados, o instrumento revelou que a amplitude e quantidade de espaços recreativos não são otimizadas no sentido em que as áreas de lazer e vivência não são bem aproveitadas. Há a carência de mobiliários como mesas e bancos, além dos poucos existentes, para que as meninas e meninos possam conversar ou realizar atividades de leitura mais confortavelmente, nos momentos em que eles não querem correr ou jogar, por exemplo. Na escola não uma horta, que pode ser um espaço com potencial de estimular outras dimensões de aprendizado, tais como o respeito e importância de preservação do meio ambiente, e também o estímulo para hábitos alimentares saudáveis.

O Mapa Cognitivo ou Mapa Mental é um dos instrumentos baseados na elaboração de 
desenhos ou relatos de um ou mais indivíduos acerca de um determinado ambiente. Sua utilização no campo da arquitetura foi difundida por Kevin Lynch, em "A imagem da cidade". O Mapa mental foi realizado nos dia 28 de outubro. Conforme sugestão da diretora da instituição, os instrumentos foram aplicados apenas para as duas turmas do terceiro ano, pois, eram turmas em que os pais eram muito presentes, o que facilitaria a obtenção de autorização para a realização das atividades, e a professora tinha um bom relacionamento e controle dos alunos. Os usuários foram abordados com uma cópia do instrumento, que havia a seguinte questão aberta: "A minha escola é...", a ser respondida através de desenhos e/ou relatos escritos, com o objetivo de perceber o quanto se conhece do ambiente analisado, através da memória.

Através da análise das fichas, pôde-se observar que os elementos da edificação estão muito presentes na representação de escola que os alunos possuem. A fachada da escola é bastante retratada, assim como os elementos como as grades, as portas, escadas, janelas, a cor correta da fachada, o nome da instituição, entre os outros aspectos (figura 7). $\mathrm{O}$ espaço do pátio foi também bastante representado nas fichas, local onde os alunos desenvolvem suas atividades recreativas. Os ambientes internos, tais como as salas de aula e o laboratório de informática também foram bem representados. A quantidade de espaços livres é também recorrente, e, mais uma vez confirma que os pátios escolares têm a sua importância no processo de aprendizagem dos alunos, e têm papel fundamental na construção de memória coletiva e afetiva dos usuários. Não houve, de modo geral, aspectos negativos relatados nas fichas.

Figura 7 - a representação da fachada da escola por um aluno.

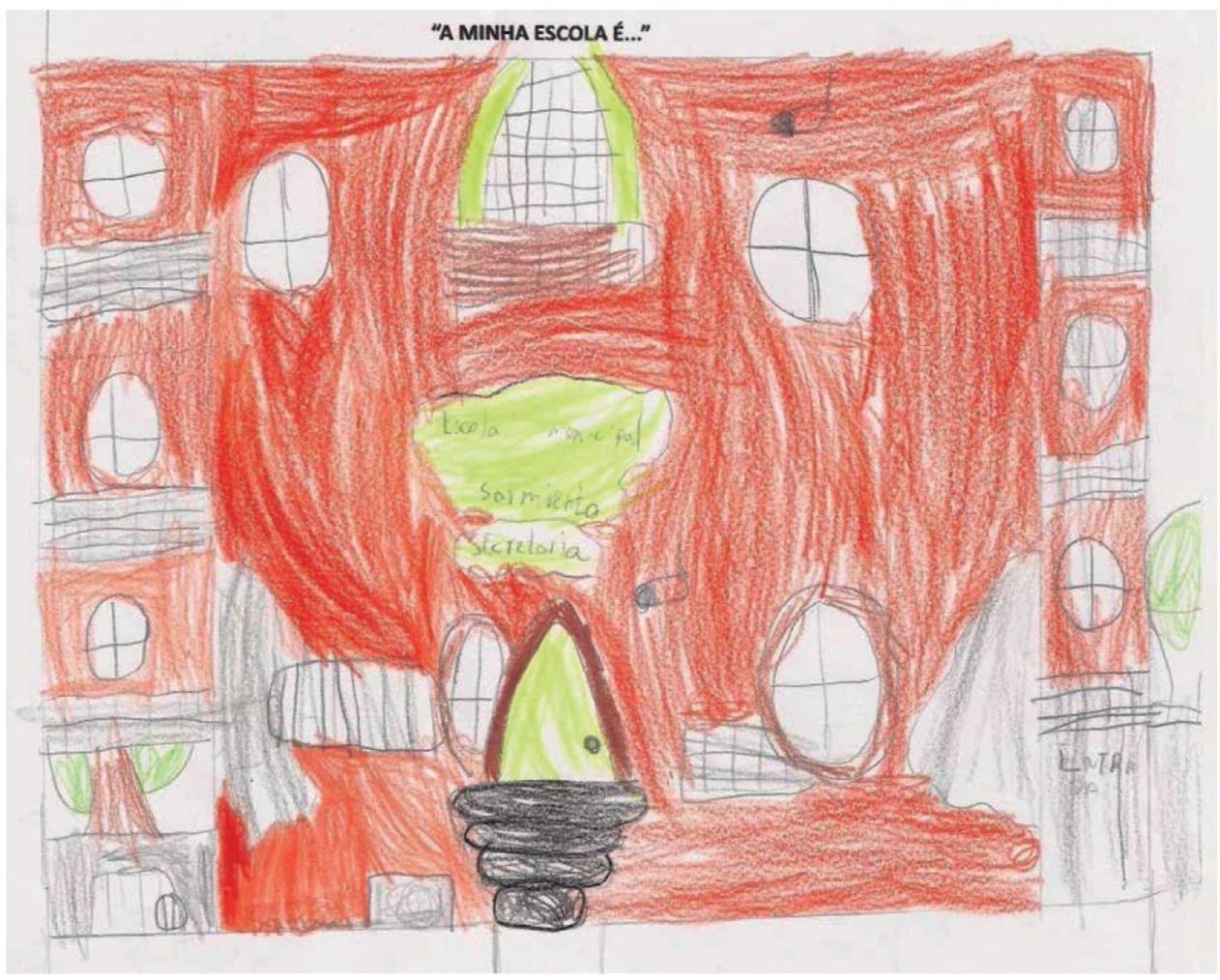

Fonte: arquivo dos autores.

O Poema dos Desejos ou Wish Poem é um instrumento não estruturado e de livre expressão que funciona em dinâmicas de grupo ou workshops, que incentiva e se baseia na espontaneidade das respostas. Sua aplicação tem como objetivo entender as necessidades, sentimentos e desejos dos usuários de um determinado ambiente. Esta técnica proporciona a identificação de um imaginário coletivo, possibilitando 
construir, após sua análise, a imagem do ambiente ideal a ser replanejado ou construído (RHEINGANTZ et. al., 2009).

A aplicação do poema dos desejos aconteceu de forma semelhante aos mapas mentais e no mesmo dia, porém após os primeiros. No instrumento havia a seguinte questão aberta: "Eu gostaria que a minha escola fosse...". Os alunos revelaram sentir falta de um espaço multimídia, com televisões e computadores a disposição deles. A questão da quadra é pertinente porque na verdade os alunos não têm esse espaço na escola, mas sim uma área livre descoberta onde as atividades de educação física são realizadas. Embora no pátio coberto existam as mesas de pingue-pongue para as crianças maiores, e alguns jogos de mesa, que ficam sob o comando das inspetoras no horário do recreio, a escola ainda carece de uma melhor organização das áreas livres, e também de mobiliários mais adequados.

A Seleção Visual tem por objetivo identificar os valores e significados agregados ao conjunto de espaços analisados, fazendo sempre que possível uma analogia com os ambientes vivenciados pelos respondentes. Sua aplicação permite identificar símbolos, aspectos culturais, preferências e tornar lúcida a imagem coletiva do ambiente construído em questão, considerando os impactos de ordem arquitetônica, espacial e social (RHEINGANTZ et al, 2009).

Figura 8 - modelo de seleção visual.

\section{SELEÇÃO VISUAL. \\ AVALLAÇĀO PÓS-OCUPAÇÃO DO AMBIENTE CONSTRUIDO.}

Marque abaixo a imagem que representa melhor a sua escola. Não é necessária a sua identificação.
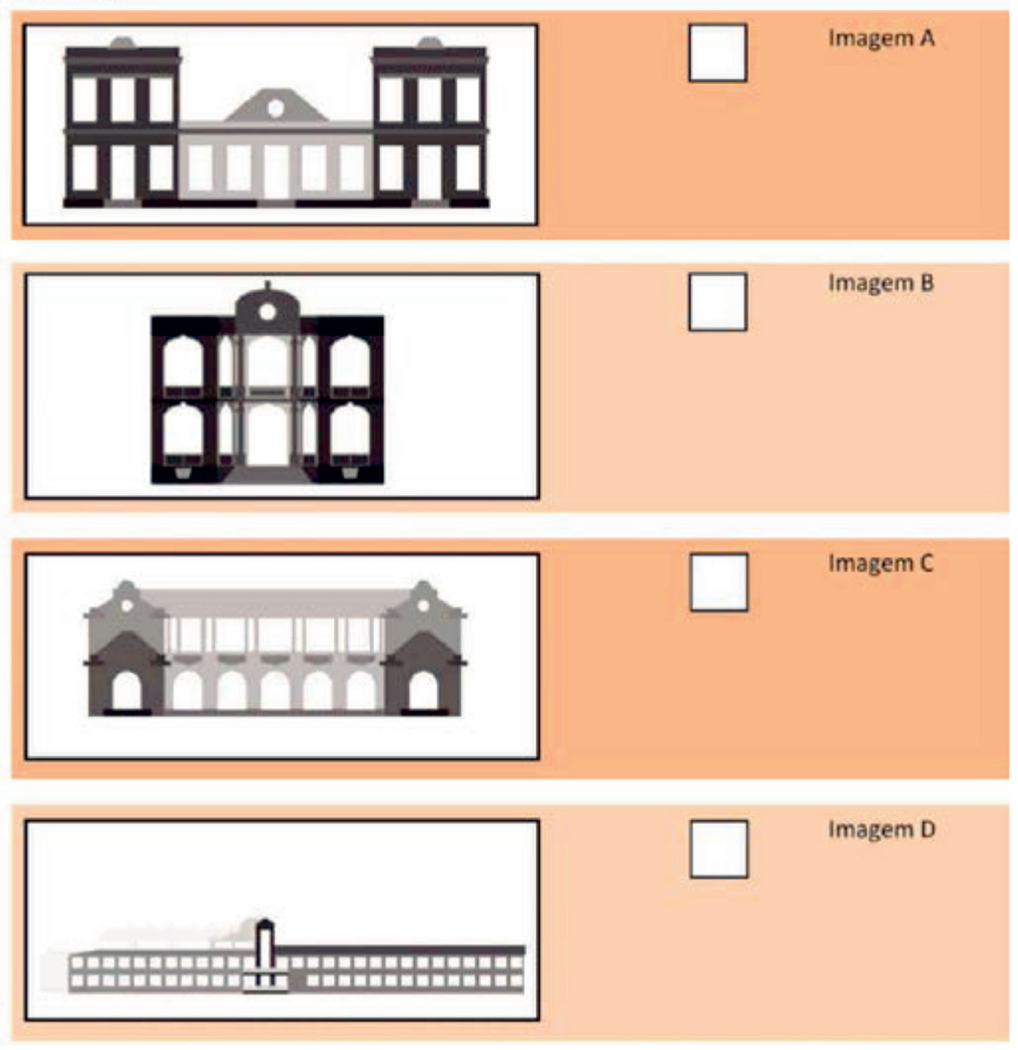

Fonte: arquivo dos autores.

A seleção visual (Figura 8) foi aplicada com os diferentes grupos de usuários da escola - alunos, professores e funcionários. Sua aplicação aconteceu durante todas as visitas à instituição. Com os alunos a aplicação aconteceu após a realização dos mapas mentais e do poema dos desejos, para que as imagens não induzissem os registros. A seleção visual 
foi composta por uma seleção de imagens, onde os respondentes deveriam marcar com um " $x$ " a imagem que mais representava a escola deles. Foram selecionadas quatro imagens representativas do modelo de arquitetura escolar carioca entre 1870 até 1945 , segundo o inventário arquitetônico de prédios escolares do primeiro grau da cidade do Rio de Janeiro, realizado por Raquel Sisson (1990). O objetivo desse instrumento era verificar se a questão do edifício, sua arquitetura e elementos compositivos, estavam presentes na memória dos usuários da escola, já que a memória, segundo a fundamentação teórica dessa pesquisa, tem papel fundamental no processo de valorização institucional e representação social positiva.

Para muitos respondentes, a imagem da escola era a imagem c, por conta principalmente dos arcos e conjunto de pilares e os telhados, muito presente na arquitetura da Escola Municipal Sarmiento. A aplicação do instrumento demonstrou que os elementos de composição do edifício estão bem fortes e presentes no imaginário dos usuários, assim como foi revelado com a aplicação dos mapas mentais e com as entrevistas. O diferencial da escola para os usuários é justamente o edifício, que possui características próprias de construção e composição, um marco referencial do bairro. Mais uma vez constata-se que a arquitetura escolar é parte fundamental da representação social de escola.

\section{Resultados e recomendações}

A adoção da Matriz de Descobertas como forma de síntese de todas as ferramentas de APO utilizadas para avaliar os ambientes da Escola Municipal Sarmiento é bastante pertinente, pois permite uma leitura rápida e clara de todos os aspectos levantados. Com a inclusão de fotos, imagens e desenhos indicados nas plantas baixas, as descobertas advindas da aplicação de cada instrumento podem ser visualizadas simultaneamente, sendo assim possível ter uma apreensão das principais informações obtidas com a aplicação de todos os instrumentos. 0 leitor, desse modo, pode ter uma noção geral dos principais aspectos positivos e negativos que permeiam o ambiente estudado, e facilita futuras propostas de intervenção e melhorias e adaptações nos ambientes da escola.

A seguir, apresenta-se a matriz de descobertas desenvolvida para a análise dos resultados obtidos através da APO no ambiente da Escola Municipal Sarmiento (figura 9):

Figura 9 - matriz de descobertas

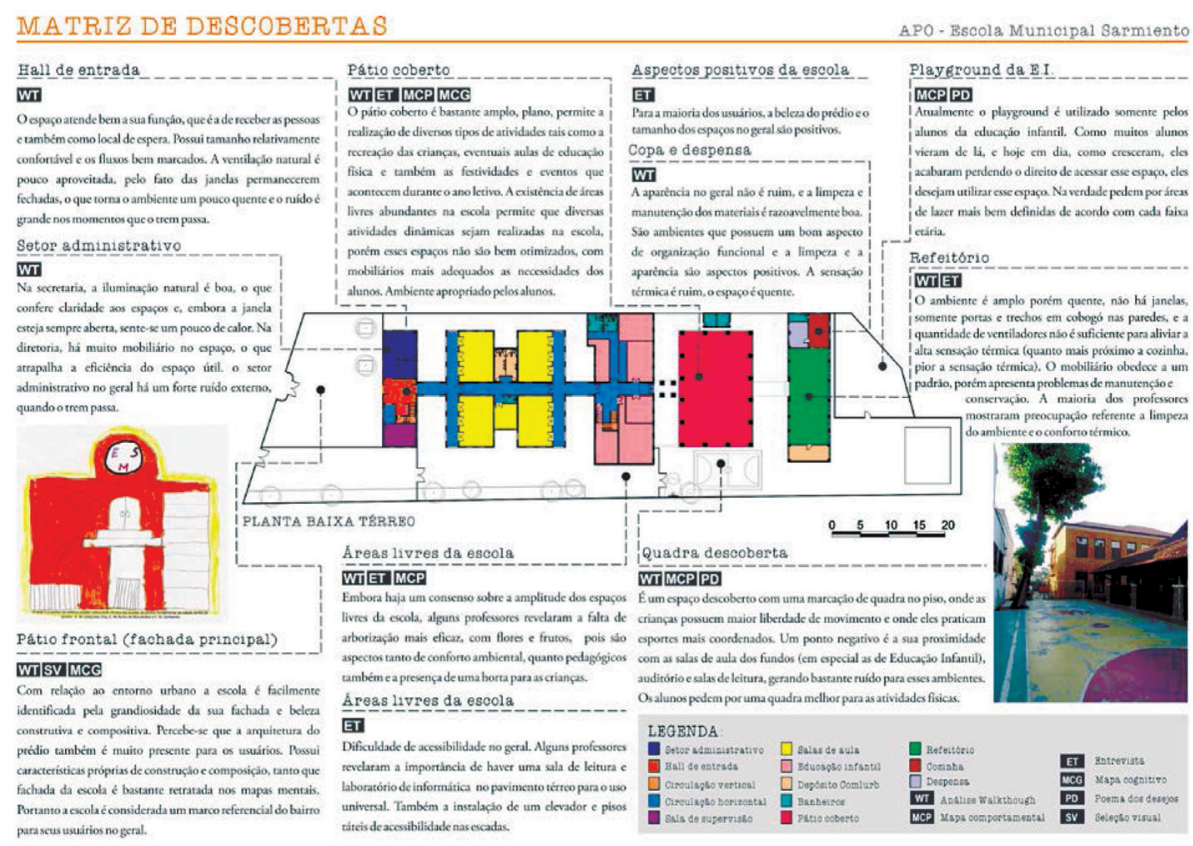




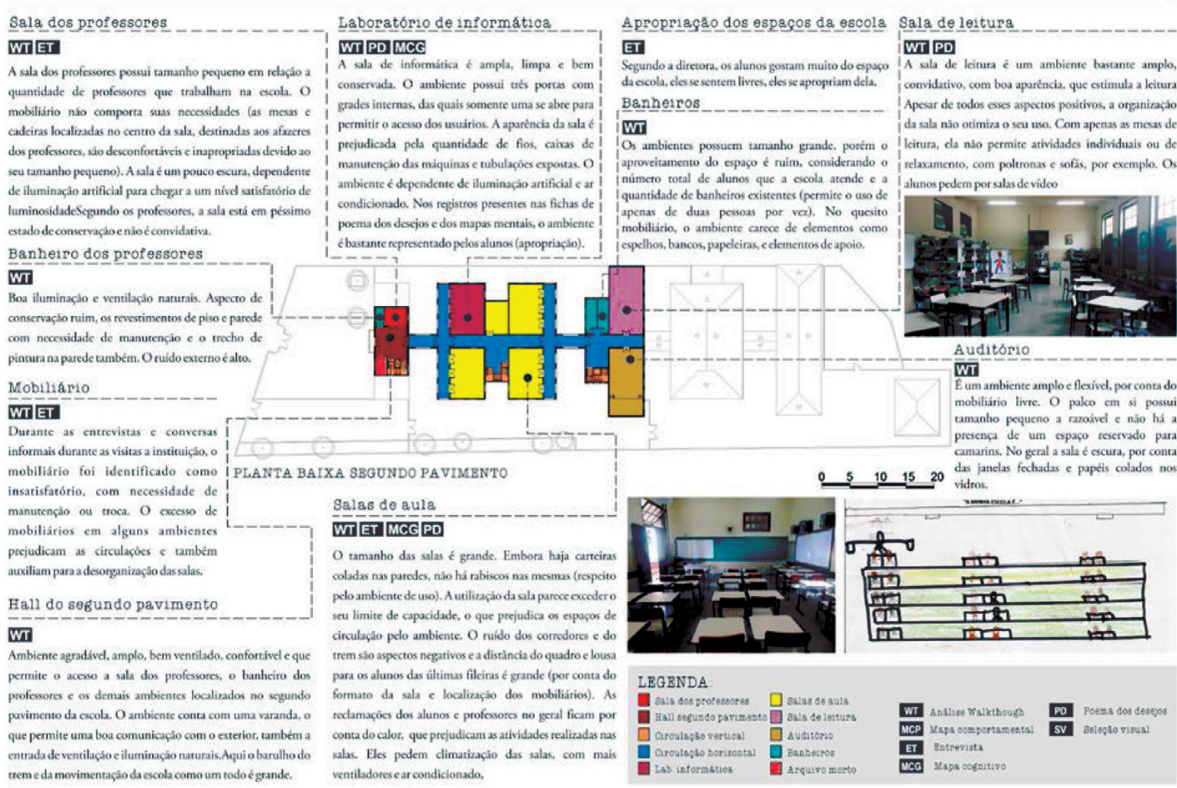

Fonte: arquivo dos autores.

As recomendações foram organizadas em forma de quadro. A partir da matriz de análises, foi possível fazer proposições relacionadas a cada um dos aspectos constatados (Quadro 2). A seguir algumas das recomendações:

\begin{tabular}{|c|c|}
\hline AMBIENTE & RECOMENDAÇÕES \\
\hline 1. Pátio frontal & $\begin{array}{l}\text { Projetar uma praça pública com equipamentos urbanos de áreas } \\
\text { livres, arborização como forma de minimizar o desconforto } \\
\text { acústico dentro da escola e a retirada ou substituição dos muros } \\
\text { altos por grades mais baixas. }\end{array}$ \\
\hline 2. Sala dos professores & $\begin{array}{l}\mathrm{Na} \text { atual sala dos professores, equipar o ambiente com mesas para } \\
\text { reuniões e tomadas no piso para o uso de notebooks, espaço para } \\
\text { armários com livros e materiais pedagógicos e um espaço de } \\
\text { apoio para copa. Tornar o ambiente favorável para a concentração } \\
\text { e pesquisa. }\end{array}$ \\
\hline 3. Banheiros & $\begin{array}{l}\text { Nos banheiros, estudar a viabilidade hidráulica para ampliação do } \\
\text { número de cabines sanitárias e até mesmo a colocação de cabines } \\
\text { com chuveiros, pois há espaço suficiente. Colocar bancos e } \\
\text { espelhos, além de manter o ambiente sempre limpo como forma } \\
\text { de estimular nos alunos o cuidado com a higiene. }\end{array}$ \\
\hline 4. Corredores & $\begin{array}{l}\text { Estimular que os alunos se apropriem do espaço como um local } \\
\text { pedagógico, através da exposição das atividades da escola em } \\
\text { murais sempre atualizados e conservados, prever espaços com } \\
\text { banco, cadeiras para ampliar a convivência e troca de } \\
\text { experiências, sem atrapalhar o fluxo de circulação, e alguns } \\
\text { ambientes propícios para a leitura. }\end{array}$ \\
\hline $\begin{array}{l}\text { 5. Salas de atividades } \\
\text { pedagógicas }\end{array}$ & $\begin{array}{l}\text { Investir primeiramente em mobiliários adequados para a } \\
\text { utilização dos alunos, como mesas e carteiras confortáveis, lousas } \\
\text { móveis para serem utilizadas conforme a sua demanda de } \\
\text { utilização. Dispor as carteiras em círculos ou pequenas estações } \\
\text { de estudos, onde os alunos e professores possam interagir da } \\
\text { melhor forma possível. Projetar espaços que estimulem a leitura, } \\
\text { espaços para descanso, educação artística e cultural e sua } \\
\text { organização deve ser o mais flexível possível. É necessário } \\
\text { readequar os espaços da escola para o acesso às novas } \\
\text { tecnologias, as salas de aula devem permitir o uso de projeções } \\
\text { nas paredes, o uso de internet em tablets e notebooks e também } \\
\text { permitir condições de uso com conforto ambiental (climatização e } \\
\text { iluminação nas salas). }\end{array}$ \\
\hline
\end{tabular}




\begin{tabular}{|l|l|}
\hline \multicolumn{2}{|c|}{ AMBIENTE } \\
\hline 6. Laboratório de informática & $\begin{array}{l}\text { Reorganizar o ambiente através da substituição dos computadores } \\
\text { por modelos mais atuais e portáteis, como tablets, notebooks e } \\
\text { smartphones. Dispor algumas mesas e cadeiras em círculos e } \\
\text { estações de trabalhos, investir na colocação de uma lousa digital } \\
\text { com acesso a internet e projeção de vídeo. A sala poderia ser } \\
\text { utilizada para que alunos pudessem desenvolver um blog da } \\
\text { escola ou para jogos online educativos e acesso a multimídia. A } \\
\text { sala poderia ter livre acesso a diferentes públicos ao mesmo } \\
\text { tempo, e seu horário de funcionamento poderia ser contínuo. }\end{array}$ \\
\hline 7. Refeitório & $\begin{array}{l}\text { Readequar o mobiliário no geral e investir em diversidade de } \\
\text { espaços mais adequados para a alimentação, promovendo a } \\
\text { diferenciação de utilização no ambiente, também como forma de } \\
\text { melhorar a movimentação nas circulações. Abrir janelas no } \\
\text { recinto por conta do calor excessivo, ou investir em climatização } \\
\text { do espaço. O refeitório poderia também ser utilizado como } \\
\text { oficina de culinária para os alunos, além do incentivo de consumo } \\
\text { de alimentos saudáveis. }\end{array}$ \\
\hline 8. Geral & $\begin{array}{l}\text { No geral essa escola apresenta um bom estado de conservação e } \\
\text { manutenção de seus espaços. A acessibilidade entre os } \\
\text { pavimentos poderia ser resolvida com a colocação de elevadores } \\
\text { próximos aos pontos de circulação vertical, o acesso dos alunos } \\
\text { poderia ser na lateral da escola de modo a contemplar o acesso } \\
\text { universal e as salas de aula bem como os banheiros e pátios da } \\
\text { escola deveriam se adequar para que portadores de necessidades } \\
\text { especiais pudessem ser contemplados também. Essas propostas } \\
\text { são mais complicadas de serem realizadas por conta do } \\
\text { tombamento do prédio, porém são necessárias. }\end{array}$ \\
\hline
\end{tabular}

Fonte: arquivo dos autores.

A Escola Municipal Sarmiento possui boas condições para o favorecimento do processo de valorização do ambiente escolar. Além da oferta de espaços de qualidade, com potencial de melhorias, os usuários da escola a identificam como um lugar de aprendizagem. Tanto nas entrevistas quanto nos mapas mentais e outros instrumentos de avaliação dos usuários, ficou bastante explícito o sentimento de pertencimento e afetividade com o ambiente construído e também nas relações interpessoais. A arquitetura do edifício é parte fundamental na representação social de escola, tanto que nos instrumentos de livre expressão, a imagem do prédio foi bastante representada e quase sempre positivamente.

Outro aspecto de considerável importância para a valorização da escola está no esforço por parte de todos os usuários para a preservação e manutenção do prédio, muito em função da política de preservação da escola. Nas salas de aula, nos corredores e nos banheiros não são encontradas pichações ou depredação do patrimônio. Isso revela a preocupação com a oferta de um espaço de qualidade para o ensino, e os alunos no geral respondem bem, porque sentem que o espaço pertence a eles também.

A construção de uma ESCOLA só é possível se, além das condições físicas, com espaços de qualidade para o aprendizado, convívio e relações sociais, as pessoas que constituem esse universo complexo se respeitem, respeitem os outros com suas individualidades, e trabalhem em prol do desenvolvimento de uma sociedade mais justa e democrática.

\section{Considerações finais}

No Brasil há vários debates acerca da evolução e do desenvolvimento da educação, com propostas inovadoras e avançadas. Porém esses fundamentos são pouco transformados em prática, em termos de pedagogia e também na reflexão sobre os espaços escolares. No geral, percebe-se que a arquitetura escolar (inclusive a contemporânea) ainda não dialoga com os objetivos da educação. Mas isso significa dizer que não é possível a adequação de usos em edifícios escolares construídos em períodos antecedentes às novas metodologias 
de ensino? De fato, essa avaliação possui muitas variantes; a primeira delas é que cada instituição apresenta um contexto individual e diferenciado. Outra questão importante é que não é só a arquitetura que deve se atualizar, mas também os gestores e professores das escolas, que precisam reconhecer o seu novo papel enquanto mediadores dos processos de aprendizagem, porque os alunos parecem que já se atualizaram nesse contexto.

É possível sim readequar essas escolas para os usos atuais, preservando o bem como patrimônio da cidade. Os órgãos de proteção ao patrimônio juntamente com as secretarias e coordenadorias de educação, educadores e arquitetos precisam juntos avaliarem as condições de uso desses espaços, a propósito da adequação e preservação das escolas, caso contrário elas tenderão a se tornarem cada vez mais obsoletas e podem até cair em desuso. Refletir sobre as reais necessidades dos novos sujeitos da escola é um dos principais caminhos para esse fim, como em grande parte essa pesquisa demonstrou.

Reformar, readequar, readaptar uma escola não representa toda a solução desse problema. A valorização dessas instituições é sim a questão principal, e para isso é fundamental entender quais são as necessidades dos novos sujeitos da escola. Os jovens de hoje vêm perdendo cada vez mais o interesse por ela (um dos principais motivos para o alto índice de evasão escolar no Brasil) muito em função da desvalorização dos seus espaços, seja porque ela não atende aos seus anseios, seja porque a sua infraestrutura é deficiente e seus ambientes muitas vezes são hostis e consequentemente não auxiliam no processo de ensino-aprendizagem.

As escolas no geral precisam se readequar aos novos tempos, questão primordial para o desenvolvimento da educação, de maneira que elas respeitem seus usuários, constituindose como reais lugares de aprendizagem, só assim as representações sociais referentes a essas instituições serão positivas, e esse quadro social certamente será formador de memórias coletivas cada vez mais favoráveis. Esse talvez seja o ciclo para a valorização da escola. 


\section{Referências bibliográficas}

AZEVEDo, Giselle Arteiro N. As Escolas Públicas do Rio de Janeiro: Considerações sobre o Conforto Térmico das Edificações. Dissertação de Mestrado. Rio de Janeiro: FAU/UFRJ, 1995.

DEL RIO, Vicente. Integrando a psicologia e a arquitetura e urbanismo por meio do projeto. In: DEL RIO, V.; DUARTE, C. R.; RHEINGANTZ, P. A. (Org.). Projeto de Lugar: colaboração entre psicologia, arquitetura e urbanismo. 1ed.Rio de Janeiro: Contra Capa; Porarq, 2002, v. 1, p. 203-210.

DUARTE, Cristiane Rose. Raízes em solo interdisciplinar. In: DEL RIO, V.; DUARTE, C. R.; RHEINGANTZ, P. A. (Org.). Projeto de Lugar: colaboração entre psicologia, arquitetura e urbanismo. 1ed.Rio de Janeiro: Contra Capa; Porarq, 2002, v. 1, p. 61-64.

LIMA, Mayumi Watanabe de Souza. Arquitetura e Educação. São Paulo: Studio Nobel, 1995.

LYNCH, Kevin. A Imagem da Cidade. Ed. Martins Fontes - São Paulo/SP - 1995

MOSCOVICl, Serge. A representação social da psicanálise. Rio de Janeiro: Zahar, 1978.

MOSCOVICl, Serge. Representações sociais: investigações em psicologia social. Editado em inglês por Gerard Duveen; traduzido do inglês por Pedrinho A. Guareschi. 11. ed. Petrópolis, RJ: Vozes, 2015.

MOUSSATCHE, H. ; MAZZOTTI, T. B. . A arquitetura escolar como representação social de escola. In: DEL RIO, V.; DUARTE, C. R.; RHEINGANTZ, P. A. (Org.). Projeto de Lugar: colaboração entre psicologia, arquitetura e urbanismo. 1ed. Rio de Janeiro: Contra Capa; Porarq, 2002, v. 1, p. 143-152.

NUNES, C. Memória e História: entre práticas e representações. 2001. (Apresentação de Trabalho/Seminário).

REIS-ALVES, Luiz Augusto dos. O conceito de lugar. Arquitextos (São Paulo), v. -, p. -, 2007.

RHEINGANTZ, P. A. ; AZEVEDO, G. A. N. ; BRASILEIRO, Alice ; ALCANTARA, D. ; QUEIROZ, M. . Observando a Qualidade do Lugar: procedimentos para a Avaliação Pós-Ocupação. Rio de Janeiro: FAU-UFRJ, 2009. v. 1. 115p .

SAGER, Fabio. Representações Sociais do ambiente físico da pré-escola. Tese de Doutorado em Psicologia. Rio Grande do Sul: UFRGS, 2002.

SANOFF, H. School Design. New York: Van Nostrand Reinhold, 1994

SISSON, Rachel. Escolas públicas do primeiro grau: inventário, tipologia e história. Arquitetura Revista, Rio de Janeiro, v. 8, p. 63-78, 1990.

SOMMER, Robert. Espaço Pessoal. Ed. Pedagógica Universitária, São Paulo, 1973.

TUAN, Yi-Fu. Espaço e Lugar: A Perspectiva da Experiência. São Paulo: Difel, 1983.

TUAN, Yi-Fu. Topofilia: um estudo da percepção, atitudes e valores do meio ambiente. São Paulo: DIFEL, 1974. 288 pp. 